\title{
Buyer Beware: Professional Preparation and TESL Certificate Programs in Canada
}

Ron I. Thomson

Significant progress has been made toward greater professional recognition for adult ESL instructors in Canada over the past decade. At the same time, an ever-increasing demand for English-language teachers, particularly abroad, has resulted in a substantial growth in the number of private companies offering short-term ESL/EFL teacher training. Often these programs make inflated claims about the worth of their certificates in the job market, undermining attempts to professionalize the field in the eyes of the public. In this article, I propose basic requirements that should be expected of any professionally adequate TESL training program. I then assess several TESL "certificate" programs from across Canada to determine to what degree they meet these minimal professional standards. I conclude with a discussion of why increasingly stringent training standards are essential if we are to promote professionalism in the field and to achieve recognition commensurate with that in other disciplines.

Dans les dix dernières années, la reconnaissance professionnelle des enseignants ALS pour adultes s'est accrue de façon importante au Canada. Pendant cette même période, la demande toujours croissante pour des enseignants d'anglais, surtout à l'étranger, a provoqué une augmentation considérable du nombre d'entreprises privées offrant une formation de courte durée en enseignement ALS/ALP. Ces programmes exagèrent souvent la valeur qu'ont leurs certificats sur le marché du travail, sapant ainsi les efforts visant la professionnalisation du domaine au regard du public. Dans cet article, je propose des critères de base qui devraient caractériser tout programme de formation professionnelle en ALS. Par la suite, j'évalue, à partir de ces normes professionnelles, plusieurs programmes "d'accréditation" TESL au Canada pour déterminer dans quelle mesure ils y répondent. Pour conclure, j'explique pourquoi il est essentiel d'établir des normes de formation de plus en plus rigoureuses si nous voulons faire valoir le professionnalisme dans notre domaine et arriver au même niveau de reconnaissance dont jouissent les autres disciplines.

Over the past decade, significant activity has been aimed at promoting professionalization in the field of adult English as a Second Language (ESL) instruction through the development of ESL teacher certification standards (Keevil Harrold, 1995; TESL Canada, 2003; TESOL, 2002; TESOL Australia, 2003). The development of standards has been particularly vigorous in 
Canada, where TESL Canada has recently established a set of minimum standards for teacher training programs (TESL Canada). TESL Canada's standards are built on a variety of precedents set by TESL Canada's provincial affiliates, most notably BC Teachers of English as an Additional Language (TEAL) certification standards, which originated in the early 1990s (Keevil Harrold). Alberta Teachers of English as a Second Language (ATESL) standards have had an equally long history (ATESL, 1995; Keevil Harrold, 1995). More recently, TESL Ontario has introduced standards that, like those of TESL Canada, borrow heavily from those established by BC TEAL (Courchêne, 2000). Although TESL Canada hopes to provide a nationally recognizable standard, among the provincial TESL organizations to date, only BC TEAL has fully replaced its own standards in favor of those of TESL Canada.

The development of provincial and national standards has coincided with substantial growth in the number of programs, both public and private, that offer TESL training. This increase in TESL training programs has stemmed not only from demands for professional standards from current ESL program administrators, ESL instructors, and applied linguists, but also from an ever-increasing demand for English-language teachers in English as a Foreign Language (EFL) contexts.

The demand for English instructors abroad has far outpaced the number of qualified instructors available. In addition, many international English teaching jobs do not require certification because employers are not willing-or able-to pay for someone with adequate training. Although this reality has been positive for the many native speakers of English who use the teaching of EFL as a passport to exotic travel (myself included), it has negatively affected attempts to gain professional recognition for the field as a whole. Instead, the relative ease with which untrained English teachers can find employment abroad continues to support the notion among many in the general public that anyone who speaks English can successfully teach it. It is somewhat ironic, then, that this global demand for English teachers has provided a lucrative market for unscrupulous organizations that claim to "certify" ESL/EFL instructors and even guarantee jobs, when, in fact, the level of training they provide is often not a necessary condition of employment in the international marketplace. On the other hand, graduates of such private programs remain unqualified to teach in most reputable ESL programs in Canada. The result is that many prospective ESL/EFL teachers are unwittingly duped into paying high fees for courses that neither provide adequate preparation nor give them access to more job opportunities than they would have without such training. 


\section{Background}

Although TESL certificates are a relatively recent phenomenon in North America, they have been basic preparation for teaching ESL to adults in Europe and some other parts of the world since the 1960s. It was at that time that International House, a private ESL school in London, developed a onemonth program aimed at giving prospective teachers basic preparation for teaching ESL. This training program eventually evolved into the popular Royal Society of Arts (RSA) Cambridge Certificate, when Cambridge University took over administration of the program in 1988 (Ferguson \& Donno, 2003). Since 1988, the RSA certificate has gone through further incarnations, most recently taking the name University of Cambridge Local Examinations Syndicate (UCLES) Certificate in English Language Teaching of Adults (CELTA). It remains one of the most internationally recognized TESL preparation programs, providing training for thousands of prospective English-language teachers annually at centers around the world (Copland, 1996; Ferguson \& Dunno). Although still a one-month (or 140-hour) program, its content continues to change to reflect new approaches in language learning and teaching. Whatever its current manifestation, a standardized curriculum is strictly enforced wherever the course is offered. Furthermore, UCLES certificate courses are administered by teacher trainers who themselves have been specifically prepared for this role by UCLES. Such standardized practice provides prospective employers with a degree of certainty about the level of preparation represented when hiring teachers with a CELTA qualification, continuing to set this training apart from hundreds of competing TESL certificate programs.

The motivation for developing the 1960 precursor to UCLES stemmed from two prevailing conditions in the field of English language at the time: a shortage of suitably trained teachers and few training programs specific to the field of TESL (Ferguson \& Donno, 2003). Much has changed since then. Although internationally there remains a shortage of suitably qualified teachers, many more programs now offer more substantial training in TESL. With one-year postgraduate diplomas and master's degrees in TESL readily accessible at major universities, even the once widely respected UCLES certificate is no longer recognized as sufficient preparation in some jurisdictions. One-month certificates are viewed by many professionals as giving prospective ESL instructors only rudimentary classroom survival skills. The Cambridge Syndicate itself (1998) describes the CELTA program as minimal preparation, after which graduates will continue to require inservice training and guidance. In other words, although it may suffice in the interim, it is less than ideal. Given the dramatic increase in the availability of more substantive TESL training, it is surprising that the certificate market continues to thrive. 
To date, little research examines the range of certificate programs available and their legitimacy as professional credentials (Ferguson \& Donno, 2003; Watt \& Taplin, 1997). In this article, I develop a set of requirements that should be minimally expected of any professional TESL training program. Although some are borrowed from Watt and Taplin's proposal, the requirements I detail are more explicit, particularly in regard to the content of such programs. I then examine a range of TESL certificate programs offered across Canada, comparing their adequacy as professional credentials. Finally, I propose further action that must be taken by bodies such as TESL Canada and its provincial affiliates to attain the goal of professional status for TESL. Although the current standards established by TESL Canada and provincial organizations are a step in the right direction, they should not be viewed as an endpoint, but as the first step toward increasingly high expectations of professionals in the field. Only through stringent standards will adult ESL instructors receive the recognition and respect that other similar professionals enjoy.

\section{Basic Requirements of Any Professionally Adequate TESL Training Program}

\section{The Content Requirement}

Since the late 1980s, there has been a significant shift in the general orientation of many TESL training programs, particularly at the postgraduate level. It has become clear that the historical emphasis on providing only basic pedagogical techniques does not sufficiently prepare teachers for the intricacies of the second-language classroom. As a result, many now argue for a more reflective approach to teacher education. According to Hedgecock (2002), language teacher education should be grounded in a reflective orientation toward both theory and practice in order to develop a teacher's ability to think critically about practice, rather than relying on mechanical teaching strategies and methods. Kumaravadivelu (2003) argues that the historical dichotomy between theory and practice is an artificial one:

The primary task of in-service and pre-service education programs is to create conditions for present and prospective teachers to acquire the necessary knowledge, skill, authority and autonomy to construct their own personal pedagogic knowledge. (p. 42)

Even the UCLES program now advocates this approach, placing a greater emphasis on the concepts and the terminology of language teaching, which they suggest will give teachers the tools necessary to engage in the sort of professional discourse that promotes ongoing learning (Copland, 1996). Some professional organizations explicitly state that teacher training must include the development of knowledge that includes a theoretical orientation 
(TESOL, 2003; TESOL Australia, 2003). A number of authors describe this new orientation as symbolic of a new post-method era in TESL (Brown, 2002; Prabhu, 1990; Richards, 2002). Instead of applying specific methods,

[an enlightened teacher's] approach to learning is the theoretical rationale that underlies everything that happens in the classroom. It is the cumulative body of knowledge and principles that enable teachers, as "technicians" in the classroom, to diagnose the needs of students, to treat students with successful pedagogical techniques, and to assess the outcome of those treatments. (Brown, 2002, p. 11)

If such reflective teaching practice is to be realized, the content of training programs must be substantial, requiring a much greater exposure to the field of applied linguistics than short courses can provide. In fact, this suggests a movement away from training, which implies a specific way of doing things (e.g., set pedagogical techniques), and a move toward providing an education that enables teachers to become autonomous from fixed techniques associated with particular approaches to language instruction. Riddle (1982) argues that a language teacher needs to have a strong grasp of metalinguistic knowledge before he or she can apply it, not simply an ability to speak the language. Reagan (1997) and Adger, Snow, and Christian (2002) suggest that the development of substantial metalinguistic knowledge should be a core requirement for even K-12 teacher training, regardless of subject area, arguing that it will enable mainstream teachers to deal with the intricacies of classrooms where ESL students are present. Grabe, Stoller, and Tardy (2000) caution, however, that metalinguistic knowledge is itself not enough. The content of applied linguistics that is so crucial to second-language teacher training is multidisciplinary in nature. It should include not only a general understanding of linguistic structure, but also psychology, anthropology, and education.

Some evidence of the need for more substantial and longer TESL preparation is demonstrated by Richards, Ho, and Giblin (1996). They found that prospective ESL instructors enrolled in an UCLES course brought with them many disparate perceptions about the approach one should take to language teaching (e.g., whether it should be teacher-centered, learner-centered, or curriculum-centered). Although it is true that individual teachers have their own teaching styles and that these should be encouraged, it is also possible that prospective teachers have misperceptions that need to be addressed. The incorporation of new knowledge encountered in a TESL preparation program into one's current perspective takes time. Richards et al. found that at the end of one month of training, the preservice teachers in their study had only just begun to generate their own reflective questions about language and teaching. This implies that after short courses, the answers to many emerging questions are left for the teachers to derive on their own, often after 
they have already begun teaching. A better approach would be to continue teacher preparation well beyond the period where reflective questions begin to emerge, equipping teachers to confront the complexities of language classrooms more adequately.

The call for more substantial training for aspiring TESL instructors implies a belief that more adequately prepared teachers will be more successful teachers. Although no research seems to exist regarding the effect of TESL training on student achievement, adequate training has been shown to have a statistically positive effect on student achievement in other subject areas. Goldhaber and Brewer (2000) found that teachers in the United States with substantial public institution certification produced more successful students than those with training in some private, less intensive programs. Similar effects should be expected across disciplines, including language teaching, although this remains to be confirmed.

\section{Other Requirements}

The requirement that TESL preparation programs include more substantial theoretical and applied linguistics content necessarily implies that the instructors of TESL preparation programs are themselves adequately qualified to provide instruction. Instructors need to have a breadth of knowledge such that they are capable of responding to students' questions and expanding on the content being presented.

Watt and Taplin (1997) provide a useful summary of several other requirements that should be minimally expected for a program to be deemed adequate. First, they argue that admission requirements for any program should go beyond the ability to pay tuition; they should also include a prerequisite undergraduate academic foundation, including some linguistics courses or equivalents, with a minimally acceptable grade point average (GPA). A university degree would suggest that the prospective teacher has developed some critical thinking skills that can be transferred to reflective practice in TESL.

Second, Watt and Taplin (1997) argue that an adequate program should provide some form of learning assessment, with the possibility of failure; otherwise, there is no way of knowing the degree to which new knowledge has been internalized. Although not mentioned by Watt and Taplin, part of such a learning assessment should be a requirement that TESL preparation programs include a supervised practicum. This is now a standard requirement for TESL Canada and TESL Ontario recognition and is increasingly requested by prospective employers.

Finally, Watt and Taplin (1997) suggest that TESL training programs need to be recognized by some larger accreditation body; this provides a degree of public accountability. This recognition can come from a widely accepted 
TESL organization such as TESL Canada and its provincial affiliates, or from a government body, as is often the case for university level programs.

\section{A Brief Examination of $\mathbf{1 0}$ Popular TESL Certificate Programs}

To determine the breadth and depth of TESL preparation programs, I evaluate 10 TESL certificates offered across Canada, describing the degree to which they meet the requirements of (a) substantial linguistics content, (b) qualified instructors, (c) sufficient entrance standards, (d) an assessment protocol, (e) a supervised practicum, and (f) accreditation by an outside body. For comparative purposes, the tuition costs for these programs is also provided. Finally, some of the claims made by the programs in regard to these requirements are also discussed.

\section{Data Sources}

Ten programs with the label "Certificate in TESL" were selected from across Canada. Some information about the TESL certificate programs analyzed for this study was obtained through direct appeal to the programs themselves, but most of the data were collected from program descriptions posted on the Internet. Of note, over a period of one year (from the end of 2002 until the end of 2003), the number of links to Web sites associated with TESL certificate programs nearly doubled. In 2002, using the search term "TESL certificate program Canada," Google, an Internet search engine, returned 6,560 hits; one year later, this had increased to 11,700. Although not all results linked to original pages, hundreds linked to training programs, many located in Canada or elsewhere. Furthermore, in both 2002 and 2003, five private companies in Canada advertised TESL certificate programs on Google's advertising sidebar. In all cases, the identities of the programs evaluated here remain anonymous. For this reason, direct quotations are not referenced.

\section{Results}

Tables 1 through 4 provide an overview of four programs that demonstrate the range of alternatives available, all with the same label: TESL certificate. From a total of 10, these four were selected for detailed discussion because they capture a wide range of TESL certificate programs being offered.

At one end of the continuum, Certificate Program A (see Table 1) clearly fits the requirements I have proposed concerning what constitutes an adequate TESL preparation course.

It has substantial content (1,170 hours), providing both practical and theoretical orientation. The instructors all have $\mathrm{PhDs}$ in a related discipline. It has strict admission requirements, requiring an undergraduate degree. Learners are assessed using typical university assessment procedures for credit courses. The preparation also provides a supervised practicum. Al- 
Table 1

Certificate Program A

\begin{tabular}{|c|c|}
\hline Type of institution & University \\
\hline Content covered & $\begin{array}{l}\text { Introduction to teaching ESL, pedagogical grammar, listening and } \\
\text { speaking, reading and writing, testing, teaching phonology, CALL, } \\
\text { classroom management, curriculum development, cross-cultural } \\
\text { communication, language and society, articulatory phonetics }\end{array}$ \\
\hline Duration & 30 semester hours (approximately 1170 class hours) \\
\hline Admission requirements & $\begin{array}{l}\text { University undergraduate degree with a minimum grade of } C \text { and } \\
\text { a TOEFL score of } 550\end{array}$ \\
\hline Assessment & University grading scheme \\
\hline Practicum requirement & Yes-University administered \\
\hline Accreditation status & Provincially accredited \\
\hline Tuition & $\$ 6,000$ \\
\hline
\end{tabular}

though Certificate Program A is not recognized by TESL Canada (principally because the program providers have not applied for recognition), it has stringent external validation because it comprises credit courses at a provincially recognized university.

Certificate Program B (see Table 2) fails the first requirement; it lacks substantial content (only 100 hours), providing only a brief overview of the field, with a particular focus on teaching strategies. The remaining requirements appear to be met. Its instructors have at least master's degrees in TESL or a related field. Program B has a two-tiered entrance requirement. If graduates wish to receive TESL Canada certification, they must possess a university degree. However, those with only high school diplomas may also be accepted, with the understanding they will not receive the TESL Canada

Table 2

Certificate Program B

\begin{tabular}{|c|c|}
\hline Type of institution & Community college \\
\hline Content covered & $\begin{array}{l}\text { Overview of TESOL, Teaching grammar, conversation, } \\
\text { pronunciation, teaching overseas }\end{array}$ \\
\hline Duration & 100 in-class hours \\
\hline Admission requirements & High school diploma \\
\hline Assessment & Final examination with passing grade of $60 \%$ \\
\hline Practicum requirement & Yes-self-arranged volunteer or work placement \\
\hline Accreditation status & TESL Canada recognition \\
\hline Tuition & $\$ 1,020$ \\
\hline
\end{tabular}




\section{Table 3}

Certificate Program C

\begin{tabular}{ll}
\hline Type of institution & Online, private company \\
\hline Content covered & Overview of TESOL teaching techniques \\
Duration & Self-paced, approximately 100 hours \\
Admission requirements & 18 years of age \\
Assessment & Graded assignments \\
Practicum requirement & Yes-self arranged volunteer or work placement \\
Accreditation status & None \\
Tuition & $\$ 500$ \\
\hline
\end{tabular}

recognized certificate. The program provides an assessment in the form of a final examination, although no other assignments are specified. In terms of the practicum requirement, although one is available, the students themselves must arrange for it at a suitable school. Moreover, the practicum is required only by those seeking TESL Canada certification. A qualified teacher must supervise the practicum, and some form of assessment is also provided by the certificate provider. A final TESL Canada recognized certificate is issued, providing that the student meets the degree and practicum requirements.

Certificate Program C (see Table 3) fails the minimal requirements for adequate TESL training on almost all fronts. It provides only a 100-hour overview of the field, and, like Certificate Program B, it focuses on teaching strategies. No teacher qualifications are provided other than that teachers are "extremely helpful" and "experts in the field." The only entrance requirement for Program $C$ is that the applicant be 18 years of age; in fact, acceptance is guaranteed within 24 hours. Although it claims to have a graded

Table 4

Certificate Program D

\begin{tabular}{ll}
\hline Type of institution & Private company \\
\hline Content covered & Overview of TESOL teaching techniques, job tips \\
Duration & 60 hours/5 days \\
Admission requirements & 18 years of age, speak English fluently \\
Assessment & None \\
Practicum requirement & None \\
Accreditation status & None \\
Tuition & $\$ 1,000$ \\
\hline
\end{tabular}


assessment, it is unclear whether students can actually fail this course. There is no practicum, as the course is administered online. Finally, Certificate Program $C$ has no status with any outside accreditation body.

Certificate Program D (see Table 4) provides an example of the lowest level of training available. The entire course lasts 60 hours (over a 5-day period). The content is a superficial overview of TESL, with most of the content focused on classroom techniques. The instructors have no reported qualifications beyond undergraduate degrees, experience teaching ESL, and a TESL certificate from the same or a similar program (confirmed in a personal conversation with the program's director). The only entrance requirements are that the applicant be 18 years of age and speak English. There is no assessment, other than a multiple-choice exam that is provided in full as part of the enrollment package. Furthermore, this exam can be retaken until it is passed. Certificate Program D does not offer a supervised practicum, although it does promise micro-teaching activities during the course of the program. Finally, this program is not recognized by any outside accreditation body, either governmental or TESL Canada affiliated.

Table 5 (see Appendix) provides an overview of the four programs outlined above in comparison with another six TESL "certificate" programs that are widely advertised across Canada and claim to train large numbers of teachers. As can be seen, the degree to which they meet minimally acceptable requirements for adequate TESL training varies. Only Certificate Program A meets the requirement that content be substantial. The other minimal requirements are met by only three of the remaining programs ( $\mathrm{H}$ and $\mathrm{J})$.

Interestingly, the programs evaluated also vary significantly in price. Although Program A is by far the most expensive, it offers the best bargain in terms of cost per hour of preparation $(\$ 5 / \mathrm{hr})$. The lowest level of training, Certificate Program D, has the highest cost per hour of instruction $(\$ 17 / \mathrm{hr})$.

\section{Discussion}

It is clear from the examination of these 10 TESL "certificate" programs that the requirement of substantial theoretical and applied linguistics content is rarely met. On the other hand, the requirements of qualified instructors, sufficient entrance standards, an assessment protocol, a supervised practicum, and accreditation by an outside body do appear to be met, but to varying degrees.

In regard to these latter requirements, the evaluation of the programs above demonstrates that the qualifications of course instructors might serve as a good first predictor of program quality, although there are obvious exceptions. Program A has a faculty that comprises entirely university professors with PhDs in related fields. The instructors in Program B have master's degrees in a related field. Program $\mathrm{H}$ has a single instructor, with a $\mathrm{PhD}$ in linguistics. Program J necessarily has UCLES-trained instructors. 
Notably, of the 10 programs evaluated, these four alone were accredited by an outside body: the first (Program A) by a provincially accredited university and the others (Programs B, H, \& J) by TESL Canada. This indicates that although TESL Canada adequately monitors some aspects of private programs, ultimately it fails in that it recognizes programs that do not have substantial content.

The remaining six programs either do not specify the level of training held by instructors, or they unashamedly acknowledge their staff's lack of TESL-specific training beyond the program's own TESL certificate. For example, instructors in one program have degrees in sociology, political science, and mathematics, in addition to a TESL certificate provided by the program itself or one similar to it. None appears to have TESL Canada or provincial affiliate recognition.

\section{Program Claims}

Some of the "certificate" programs examined make unsubstantiated claims in their advertising information about the proposed requirements. These claims pertain primarily to the content of the programs, accreditation status of the programs, and resulting guarantees of employment. Program A makes no unsubstantiated claims about the proposed requirements, appearing to meet or exceed all of them. The claims made by other programs vary; because Program D least adequately meets the proposed requirements, its claims to the contrary are consequently the most egregious.

Content. Programs B and C both claim to provide a comprehensive overview of teaching techniques. These claims are difficult to assess, although 100 hours of instruction seems inadequate for any "comprehensive" introduction to the field. Programs B and C do not make claims about content areas related to linguistics, psychology, anthropology, or education.

The most outrageous example of a false statement about course content comes from Program D, which claims to have produced and copyrighted their "original" teacher resource training manual. Given that some of the content seems quite good, this assertion implies that the course developers and instructors are relatively expert. The inside cover of their manual states:

Produced and licensed by [Program D]. Copyright 2003 [Program D]. as registered by the Province of Alberta and by the Government of

Canada. International Copyright 2003 [Program D].

The content of the manual itself, however, is inconsistent; some parts of it are clearly well written and others poorly written. As a colleague of mine began examining the manual, she recognized elements from two chapters taken word for word from a text (Raimes, 1983) on teaching writing. This source is not cited in Program D's manual, and the material is clearly represented as original work. After further comparison with the original author's 
book (Raimes, 1993) we established that 14 pages had been plagiarized verbatim from the text. Similarly, the section on grammar instruction in Program D's manual was taken from Larsen-Freeman's (1991) chapter on teaching grammar. Again, the copyright falsely indicated that Program D authored the material. Furthermore, it was determined that the entire linguistics section in the Program D manual was lifted verbatim from Microsoft Encarta's introduction by Klima (2003), again without citation. Although no further checks were made, it is clear that large portions of the manual are not the intellectual property of Program D.

That intellectual property rights have been so blatantly violated is especially ironic considering that Program D's manual has the following warning on the first page:

Course content, course structure, manuals, handouts, brochures, certificates, transcripts, institute logo, website, and all other intellectual property associated to all courses and products offered by [Program D] is strictly protected under international copyright laws. Any such student, person or corporation infringing on the copyright law pertaining to the materials and intellectual properties stated will be prosecuted to the full extent of the law.

Clearly Program D did not respect the similar warning in the copyrighted materials from which they plagiarized.

Program $D$ is not the only one to make unsubstantiated claims about course content. The deliverers of Program E (see Table 5) maintain that they "offer one of the most comprehensive TESL programs in Canada" as well as purporting to serve as advisors to various international organizations and corporations, including the United Nations. In terms of course content, in only 130 hours of class time, they indicate that they "have the highest level of acquisition of all the courses, and ... prepare [their] students for all aspects of life overseas." Furthermore, they suggest that they have "take[n] the lead from such well known universities as Harvard University and McGill University, [by now offering] a full semester of International TESOL training in a new and innovative campus/off campus format." Such claims sound impressive and may be taken at face value by uninformed clients.

Accreditation. Although only Programs A, B, H, and J are accredited by TESL Canada or a provincial government, Programs $D$ and $E$ also claim to be accredited by outside bodies. Program D states that it is an "internationally recognized TESOL course-accredited by the Canadian government and endorsed by over 10,000 schools internationally." On further research, it was found that this company is registered with the Canadian and Alberta governments as a private school for tax purposes, but it is not accredited by either. Such assertions are interesting in the light of the company's motto, "Honesty and integrity in doing business." Furthermore, Program D's certifi- 
cate is embossed with a logo indicating its recognition by TESOL Licensing Standards International. In a telephone interview, Program D's owner conceded that this accreditation body does not exist and is in fact one and the same as Program D.

Program $\mathrm{D}$ is not the only one to establish its own accreditation body to avoid the necessity of legitimizing its status with nationally recognized bodies such as TESL Canada or one of its provincial affiliates. Program E also founded its own accreditation body, describing its mandate as "assess[ing] teaching credentials and experience and promot[ing] quality instruction and student safety in schools." As of 2004, no other TESL training programs was listed as being accredited by this organization.

The practical effect of accreditation is the recognition of a certificate by potential employers. Hence a common enticement of private certificate programs is the guarantee that with their certificate, customers will easily obtain jobs. All the programs outlined here either offer job guarantees or state that their certificates constitute the basic credential for finding ESL/EFL teaching positions. Again, Program D (see Table 4) was the most explicit in this regard, claiming to have the "highest job placement rate of any TESOL course worldwide." However, this program does not explicitly guarantee that jobs will be found in Canada. When questioned, Program D personnel qualified its guarantee with the statement that the prospective teacher must be willing to relocate (personal communication, January, 2004).

To test the claim that TESL certificates are necessary to obtain employment abroad, I conducted a brief survey of recent international job postings on one of the first and most popular English teaching job boards on the Web, Dave's ESL Cafe (http:/ / www.eslcafe.com). A sampling of the latest 34 jobs listed (in February 2004) clearly demonstrates that many international jobs can be obtained without a TESL certificate (see Table 6 in Appendix). Nearly half ( 15 out of 34 ) required a bachelor's degree but no TESL certificate. Only eight of 34 specified that some form of certificate was required, whereas seven of these also required a bachelor's degree. Only one required simply an International English Language Testing System (IELTS) certificate, with no degree requirement specified. However, because IELTS is a specific type of certificate demonstrating English language proficiency, none of the private certificates discussed here would be accepted. These results indicate that the primary credential for work abroad, and the one that will guarantee a job in most markets with or without a TESL certificate, is a university degree. Govardhan, Nayar, and Sheorey (1999) found similar variations in the requirements of employment listed in newspaper advertisements recruiting teachers for the international English teaching market. In one major newspaper, only $10 \%$ of the positions advertised asked for specific ESL/EFL training, the rest listing a range of other requirements, most often a bachelor's degree. 


\section{Conclusion}

This brief examination of the range of TESL "certificate" programs available in Canada clearly demonstrates that there is no cohesive definition of what constitutes a TESL certificate. Although some programs, such as Certificate Program A, offer a level of training that, I argue, qualifies as a professional credential (see Table 1), many offer only a minimally acceptable introduction to the field. Two-tiered programs such as Certificate Program B, to which applicants are admitted without an undergraduate degree, are far from ideal. Although the content may be legitimate, underprepared participants may not be able to participate fully in classroom discourse, thus creating a poor learning environment for those who can. Many programs (6 of 10 in this study) do not meet even minimally acceptable standards for TESL preparation. Those with the weakest standards often make inflated claims about their own courses that unsuspecting and uninformed potential clients have no way of verifying.

The emergence of TESL certificate programs in such phenomenal numbers, although on one hand undermining the credibility of the field, also underscores a major shift in attitudes toward the teaching of ESL. Whereas being a native speaker was historically the only prerequisite for teaching a language, the popularity of certificates, however illegitimate, suggests there is growing recognition that teaching ESL or EFL requires some preparation.

Although TESL Canada has made significant strides in providing a more cohesive framework for what those qualifications should be, this organization, nonetheless, groups together programs that do not share common standards. The $39+$ programs that currently hold TESL Canada recognition range from UCLES' month-long courses (and other private courses similar to UCLES') at one end of the continuum, to university graduate degree programs in TESL at the other. Clearly these are not equivalent. However, they are treated as such for the first three of the four TESL Canada certification levels. Interestingly, many university-administered TESL programs, including Program A, have not yet applied for TESL Canada recognition. Their hesitancy in jumping on board with TESL Canada may be because TESL Canada's multi-tiered approach does not adequately discriminate among the alternatives available. In addition, given that government bodies already recognize their programs, universities may feel that little is to be gained by paying TESL Canada substantial fees for recognition. The unfortunate consequence is that, although only universities appear currently to offer the sort of professional training that adequately meets professional requirements, the small number that have applied for recognition by TESL Canada adversely affects TESL Canada's own status as a professional organization. 


\section{Recommendations}

One reason the ESL/EFL profession does not enjoy higher status as a profession, with commensurate salaries, is that it is widely viewed as being easy to enter (Ferguson \& Donno, 2003). If admission to the field were more restricted, TESL/TEFL would become more of a profession and less of a short-term or part-time job.

TESL Canada is in a position to play a greater role in ensuring that TESL preparation programs have adequate content coverage, are taught by qualified instructors, and are aimed at students who are capable of a high level of training. TESL Canada's standards (TESL Canada, 2003) clearly exclude many private programs that do not meet minimally desirable standards. However, they also include many programs that provide only the beginning stage of TESL preparation: what UCLES itself views as merely the first step toward more extensive and necessary professional development (Ferguson \& Donno, 2003). Although the recognition of some 100-hour TESL certificate programs may be necessary in the short term to meet the demand for minimally prepared teachers, it is essential that TESL Canada continue to raise its standards as graduates from more intensive and comprehensive programs enter the job market. One-month certificates, including those of UCLES, should not enjoy permanent status as adequate credentials if the general public's view of TESL as a legitimate profession is to materialize. Private programs that offer TESL Canada-recognized credentials should eventually be required to undergo much stricter assessment procedures than currently when applying for TESL Canada recognition. Although public institutions such as universities undergo regular program reviews by internal and external regulatory bodies, private TESL training programs do not receive such rigorous scrutiny. As a result, although TESL Canada (2003) stipulates the type of course content that must be addressed in a certificate program-and how the program should be structured-it is difficult to ensure adequately that private institutions that have no external program review procedures are actually held to TESL Canada requirements. For such private programs, the mail-in process through which they receive TESL Canada recognition should eventually be replaced by TESL Canada site visits. In addition, TESL Canada might consider waiving application fees for programs at government-recognized universities. By automatically recognizing all university-level programs of adequate length, TESL Canada would bring the most important players on board and, in the process, enhance its own credibility.

It may also be worth considering an eventual move away from the use of the term certificate to identify acceptable TESL credentials; it is primarily associated with short courses. Only Certificate Program A provided truly substantial preparation. Many comparable programs at other universities label their credential a "diploma." As the demand for more vigorous 
preparation emerges, a term such as diploma, which is generally associated with credit courses, may more appropriately represent the status of Program A.

Perhaps the most important players for encouraging the continuing professionalization of the field of TESL in Canada are the language programs that hire teachers. Although TESL Canada can set standards, it is language programs that will make professional recognition valued. Not only should language programs encourage their instructors to pursue professional development and accreditation, they should also offer monetary incentives for higher levels of expertise. TESOL (2003) states that programs should strive to provide salaries and benefits that are "commensurate with those of instructional and professional staff with comparable positions and qualifications within similar institutions" (p. 23). Although one might argue that monetary incentives should not be necessary for ESL teachers to conduct themselves professionally, the reality is that the lack of some form of reward implies that employers do not value professional training. This indirectly contributes to the belief that ESL teachers are unprofessional (Slomp, 1999). If language programs demand greater expertise from their instructors, this will lead to stronger preparation programs and, perhaps inevitably, the demise of private certificate programs that cannot provide that expertise.

As the number of highly trained TESL professionals grows, so will recognition of the field's status. This will allow instructors to demand better salaries and more stable employment conditions, and most important, it will ensure improved learning opportunities for ESL learners.

\section{Acknowledgments}

I thank Tracey Derwing, Marian Rossiter, Leila Ranta, and Murray Munro for their helpful feedback throughout the writing of this article. I am also grateful to three anonymous reviewers and to the editors of this special issue for their useful comments and suggestions.

\section{The Author}

Ron Thomson is currently a doctoral student in linguistics at the University of Alberta: $\mathrm{He}$ completed an MEd in TESL at the same university. He has taught EFL in Kotea and Oman and ESL in Vancouver and Edmonton.

\section{References}

Adger, C.T., Snow, C.E., \& Christian, D. (Eds.). (2002). What teachers need to know about language. Washington, DC: Center for Applied Linguistics; McHenry, IL: Delta Systems.

Alberta Teachers of English as a Second Language. (1995). Best practice guidelines for adult ESL/LINC programming and instruction in Alberta. Edmonton, AB: Government of Alberta Advanced Education and Career Development and Government of Canada Citizenship and Immigration.

Brown, H.D. (2002). English language teaching in the "post-method" era: Toward better diagnosis, treatment, and assessment. In J.C. Richards \& W.A. Renandya (Eds.), Methodology in language teaching: An anthology of current practice (pp. 9-18). Cambridge, UK: Cambridge University Press. 
Copland, F. (1996). Some implications for overseas centres of the revised RSA/UCLES Cert. TEFLA syllabus. English Language Teaching Education and Development, 2, 16-30.

Courchêne, R. (2000). Certification and standards. Retrieved November 25, 2003, from http://www.teslontario.ca/cert/cert.html

Ferguson, G., \& Donno, S. (2003). One-month training courses: Time for a change? ELT Journal, $57,26-33$.

Goldhaber, D.D., \& Brewer, D.J. (2000). Does teacher certification matter? High school teacher certification status and student achievement. Educational Evaluation and Policy Analysis, 22, 129-145.

Govardhan, A.K., Nayar, B., \& Sheorey, R. (1999). Do U.S. MATESOL programs prepare students to teach abroad? TESOL Quarterly, 33, 114-125.

Grabe, W., Stoller, F.L., \& Tardy, C. (2000). Disciplinary knowledge as a foundation for teacher preparation. In J.H. Hall \& W.G. Egglington (Eds.), The sociopolitics of English language teaching (pp. 178-194). Toronto, ON: Multilingual Matters.

Hedgcock, J.S. (2002). Toward a socioliterate approach to second language teacher education. Modern Language Journal, 86, 299-317.

Keevil Harrold, D. (1995). Accreditation/certification for adult ESL instructors in Canada: An overview. TESL Canada Journal, 13(1), 37-62.

Klima, E.S. (2003). Phonetics. Microsoft Encarta reference library. Redmond, WA: Microsoft Corporation.

Larsen-Freeman, D. (1991). Teaching grammar. In M. Celce-Murcia (Ed.), Teaching English as a second or foreign language (pp. 279-295). Boston, MA: Heinle \& Heinle.

Kumaravadivelu, B. (2003). Beyond methods: Macrostrategies for language. New Haven, CT: Yale University Press.

Prabhu, N. (1990). There is no best method-Why? TESOL Quarterly, 24, 161-177.

Raimes, A. (1983). Techniques in teaching writing. New York: Oxford University Press.

Reagan, T. (1997). The case for applied linguistics in teacher education. Journal of Teacher Education, 48, 185-196.

Richards, J.C. (2002). 30 years of TEFL/TESL: A personal reflection. RELC Journal, 33(2), 1-34.

Richards, J.C., Ho, B., \& Giblin, K. (1996). Learning how to teach in the RSA Cert. In D. Freeman \& J.C. Richards. (Eds.), Teacher learning in language teaching (pp. 242-259). Cambridge, UK: Cambridge University Press.

Riddle, M. (1982). Linguistics for education. In R. Carter (Ed.), Linguistics and the teacher (pp. 31-51). London: Routledge \& Kegan Paul.

Slomp, D.H. (1999). Professionalizing ATESL: An examination of the process. Unpublished master's research project, University of Alberta.

Teachers of English to Speakers of Other Languages. (2002). Standards for teachers of adult learners. Alexandria, VA: Author.

Teachers of English to Speakers of Other Languages. (2003). Standards for adult education programs. Alexandria, VA: Author.

TESL Canada. (2003). TESL Canada Federation teacher training program standards. Burnaby, BC: Author.

TESOL Australia. (2003). Professional standards for TESOL practioners: What makes an accomplished TESOL teacher in Australia? Retrieved November 25, 2003, from http//: www.tesol.org.au

University of Cambridge Local Examinations Syndicate (UCLES). (1998). CELTA: Syllabus and assessment guidelines for course tutors and assessors. Cambridge, UK: Author.

Watt, D., \& Taplin, J. (1997). The least one should expect of TESL/TEFL programs. TESL Canada Journal, 14(2), 72-74. 


\section{Appendix}

Table 5

Summary of 10 Canadian TESL Certificate Programs

\begin{tabular}{llrlllll}
\hline Program & $\begin{array}{c}\text { Type of } \\
\text { institution }\end{array}$ & $\begin{array}{c}\text { Total } \\
\text { hours }\end{array}$ & $\begin{array}{c}\text { Degree } \\
\text { required }\end{array}$ & Assessment & Practicum & $\begin{array}{r}\text { Tuition } \\
\text { * }\end{array}$ & $\begin{array}{c}\text { TESL Canada } \\
\text { or provincial } \\
\text { recognition }\end{array}$ \\
\hline A & University & 1,170 & Yes & Yes & Supervised & $\$ 6,000$ & Yes \\
B & College & 100 & No & Yes & Self-organized & $\$ 1,020$ & Yes \\
C & Private/Online & 100 & No & Yes & None & $\$ 500$ & No \\
D & Private & 60 & No & No & None & $\$ 1,000$ & No \\
E & Private & 130 & Yes & Yes & Supervised & $\$ 1,085$ & No \\
F & Private & 100 & No & Yes & Optional & $\$ 950$ & No \\
G & Private & 120 & No & No & None & $\$ 995$ & No \\
H & Private & 200 & No & Yes & Supervised & $\$ 2,774$ & Yes \\
I & Private/Online & 130 & No & Yes & None & $\$ 1,400$ & No \\
J & UCLES/CELTA & 140 & No & Yes & Supervised & $\$ 2,300$ & Yes \\
\hline
\end{tabular}

${ }^{*}$ Tuition fees charged at time of writing.

Table 6

34 Jobs Posted on Dave's ESL Cafe Job Board

$B A$

15

$B A+$ TESL Certificate

6

$B A+C E L T A$

1

$M A$ in TESL

4

Trinity London one-year Diploma

1

IELTS Certificate

1

No requirement

4

"Most recent jobs posted in February 2004. 